\title{
Forage mixtures for dairy cows: the effect on dry matter intake and milk production of incorporating different proportions of maize silage into diets based on grass silages of differing energy value
}

\author{
R. H. PHIPPS, R. F. WELLER AND A. J. ROOK \\ AFRC Institute for Grassland and Environmental Research, Church Lane, Shinfield, Reading RG2 $9 A Q, U K$
}

(Revised MS received 28 October 199I)

\begin{abstract}
SUMMARY
During weeks 3-23 of lactation, 63 multiparous and 28 primiparous Friesian cows were offered ad libitum access to grass silage of either average $(A)(\mathrm{ME} 10.6 \mathrm{MJ} / \mathrm{kg} \mathrm{DM} ; \mathrm{CP} 158 \mathrm{~g} / \mathrm{kg} \mathrm{DM}$ ) or low (L) (ME 9.9 MJ $/ \mathrm{kg} \mathrm{DM} \mathrm{;} \mathrm{CP} 154 \mathrm{~g} / \mathrm{kg} \mathrm{DM}$ ) energy value, either alone or in mixtures consisting of one of these grass silages with 25,50 or $75 \%$ of the forage DM as maize silage. In addition, all cows received $7.2 \mathrm{~kg} \mathrm{DM} /$ day of concentrate (ME $12.9 \mathrm{MJ} / \mathrm{kg} \mathrm{DM}$; CP $202 \mathrm{~g} / \mathrm{kg} \mathrm{DM}$ ). There was a significant $(P<0.001)$ linear relationship between silage DM intake and percentage maize inclusion with grass silage. For grass silage $A, \mathrm{DM}$ intake of the mixture of grass and maize in a 1:1 DM ratio was significantly $(P<0.001)$ higher that at other inclusion levels. There was a significant $(P<0.05)$ overall linear effect of proportion of maize on milk yield, with a regression coefficient of $0.022 \pm 0.009 \mathrm{~kg} /$ day per percentage maize proportion. Although milk composition was unaffected by treatment, there was a significant $(P<0.01)$ linear effect of maize proportion on protein yield for grass silage $L$, the regression coefficient being $0.8 \pm 0.03 \mathrm{~g} /$ day/percentage maize proportion. The mixture of grass silage $A$ and maize silage in a 1:1 DM ratio produced the highest yield of milk protein.
\end{abstract}

\section{INTRODUCTION}

The $7 \mathrm{~m}$ ha of grassland in the UK provide the most important single source of forage for grazing and conservation for ruminant livestock production. However, with the introduction of milk quotas, many dairy farmers have attempted to place greater reliance on home-grown forage while decreasing concentrate inputs, with the objective of reducing input costs. To achieve this objective, it is essential to provide well fermented silage with a high energy value and high intake potential. These criteria are not easily achieved on a regular basis with grass, which has encouraged producers to consider the potential for integrating other forage sources into rations based on grass silage.

Pain \& Phipps (1975) established that maize silage was cheaper to produce than grass silage, as it required lower energy inputs. Subsequent short term studies showed that the incorporation of maize silage into dairy cow rations based on grass silage markedly increased forage intake (Weller \& Phipps 1985, 1986).
A further trial using a grass: maize silage (1:2 DM) mixture not only confirmed the beneficial effect of maize silage on forage intake, but also showed its potential to reduce concentrate inputs and improve milk quality (Phipps et al. 1988).

The production of earlier maturing maize hybrids, more suited to the cooler climate of northern Europe, and the greater awareness of the potential problems associated with the use of high levels of nitrogen fertilizer, has led to renewed interest in the role of maize in ruminant production.

The objective of the experiment presented here was to determine the effect of incorporating different proportions of maize silage with grass silages of different energy value on feed intake, milk yield and milk composition.

\section{MATERIALS AND METHODS}

During the winter of $1987 / 88,28$ primiparous and 63 multiparous Friesian dairy cows were housed in cubicle yards with sand for bedding and were 
individually fed through Calan-Broadbent gates. In weeks 1 and 2 of lactation, all cows received 7 and $8 \mathrm{~kg}$ fresh weight/day respectively, of a concentrate supplement containing $691,78,205$ and $26 \mathrm{~g} / \mathrm{kg}$ of barley, wheat, soya bean meal and minerals/vitamins, respectively. The crude protein $(\mathrm{CP})$, neutral detergent fibre (NDF), starch and metabolizable energy (ME) concentration of the supplement was 202, 204 and $444 \mathrm{~g} / \mathrm{kg} \mathrm{DM}$ and $12.9 \mathrm{MJ} / \mathrm{kg} \mathrm{DM}$, respectively. In addition they were offered a forage mixture (1:1 DM) of perennial ryegrass (Lolium perenne $\mathrm{cv}$. Melle) silage of a low $(L)$ energy value and maize (Zea mays cv. Leader) silage. The grass silage was harvested in midJune as first-cut silage to which formic acid was applied at the rate of 3 litres/t fresh material. The forage maize was harvested in early October and ensiled with no additive.

At week 3 of lactation, cows were assigned to blocks according to calving date and milk yield at week 2 , and allocated at random within blocks to treatments. Treatments were based on forage mixtures of maize silage and grass silage of either low $(L)$ or average $(A)$ energy value in which maize formed $0,25,50$ or $75 \%$ of the silage DM. Grass silage $L$ and maize silage were the same as those used in weeks 1 and 2. Grass silage $\boldsymbol{A}$ was harvested in early May as first-cut silage to which formic acid was applied at the rate of 3 litres/t fresh material. The composition and nutritive value of the forages are shown in Table 1. During weeks 3-23 of lactation, forage was offered ad libitum and all cows received $8 \mathrm{~kg}$ fresh weight/day of the same concentrate as that offered in week 2 .

Table 1. Chemical composition and nutritive value of grass silages with low (L) and average (A) energy concentration and maize silage

\begin{tabular}{|c|c|c|c|}
\hline & \multicolumn{2}{|c|}{ Grass silage } & \multirow{2}{*}{$\begin{array}{l}\text { Maize } \\
\text { silage }\end{array}$} \\
\hline & $L$ & $A$ & \\
\hline Toluene DM $(\mathrm{g} / \mathrm{kg})$ & 260 & 266 & 273 \\
\hline \multicolumn{4}{|l|}{ Composition of DM $(\mathrm{g} / \mathrm{kg})$} \\
\hline Crude protein & 154 & 158 & 80 \\
\hline Acid detergent fibre & 343 & 339 & 316 \\
\hline Neutral detergent fibre & 580 & 532 & 576 \\
\hline $\begin{array}{l}\text { In vitro digestible organic } \\
\text { matter in the } \mathrm{DM}\end{array}$ & 620 & 660 & 670 \\
\hline \multicolumn{4}{|l|}{ Fermentation acids ( $\mathrm{g} / \mathrm{kg}$ DM) } \\
\hline Lactic & $76 \cdot 8$ & $62 \cdot 4$ & $58 \cdot 4$ \\
\hline Acetic & 31.8 & $42 \cdot 4$ & 48.0 \\
\hline Propionic & 1.6 & 4.5 & $2 \cdot 0$ \\
\hline Butyric & $2 \cdot 7$ & 8.8 & $2 \cdot 0$ \\
\hline Ammonia- $\mathrm{N}(\mathrm{g} / \mathrm{kg}$ total $\mathrm{N})$ & 62 & 93 & 110 \\
\hline $\mathrm{pH}$ & 3.7 & $4 \cdot 0$ & 3.6 \\
\hline $\begin{array}{l}\text { Metabolizable energy } \\
(\mathrm{MJ} / \mathrm{kg} \mathrm{DM})\end{array}$ & $9 \cdot 9$ & 10.6 & $10 \cdot 9$ \\
\hline
\end{tabular}

\section{Feed preparation, measurements and analysis}

Forage mixtures were prepared by blending the silages in the appropriate proportions in a Butler-Oswalt 280 mixer wagon. Forage was offered at $08.30 \mathrm{~h}$ while concentrates were offered in two equal feeds at 08.30 and $16.00 \mathrm{~h}$.

Feed refusals of between 5 and $10 \%$ of that offered were removed and recorded every Monday, Wednesday and Friday. Milk yields were recorded daily. Milk samples taken at two consecutive milkings once a week were analysed for fat, protein and lactose concentration using a Milkoscan (model 203B, Foss Products, York). All animals were weighed weekly and liveweight change was calculated from the weights at weeks 3 and 23 . The experimental period lasted from weeks 3 to 23 of lactation.

Because of unequal replication between treatments, results were analysed using generalized linear regression. Mean values over the experimental period were analysed for all variables with the corresponding value in week 2 of lactation being used as a covariate.

\section{RESULTS}

Mean silage intake, milk yield, yield and concentrations of milk constituents and liveweight change recorded during weeks 3 to 23 of lactation, and adjusted for values in week 2 , are shown in Table 2 .

Silage DM intake differed significantly $(P<0.05)$ between the two grass silages; the adjusted means being 6.9 and $8.0 \mathrm{~kg} /$ day for diets based on grass silages $L$ and $A$ only, respectively. There was a significant $(P<0.05)$ linear relationship between adjusted silage DM intake $(\mathrm{kg} / \mathrm{day})$ and percentage maize inclusion for grass silage $L$. The regression coefficient was $0.024 \pm 0.0059(P<0.001)$. For grass silage $A$ the DM intake of the mixture containing grass and maize in a 1:1 DM ratio was significantly $(P<0.001)$ higher than of the other mixtures tested.

There was no significant effect of grass silage quality on milk yield, but there was a significant $(P<0.05)$ overall linear effect of level of maize inclusion on milk yield. While the regression coefficient of abdjusted milk yield ( $\mathrm{kg} /$ day) on percentage maize inclusion for grass silage $L(0.031 \pm 0.0105)$ was significant $(P<0.05)$, that for grass silage $A(0.012 \pm 0.0148)$ was not. The pooled regression coefficient $(P<0.05)$ for both silages was $0.022 \pm 0.009 \mathrm{~kg} /$ day per percentage maize inclusion.

There were no significant $(P>0.05)$ differences in milk composition between treatments. Similarly there was no change in milk fat yield. However, for milk protein yield there was a significant $(P<0.05)$ effect of grass silage quality, the adjusted means being 758 and $785 \mathrm{~g}$ /day for silages $L$ and $A$, respectively. There 
Table 2. Adjusted mean values for dry matter intake, milk production and liveweight change during weeks 3-23 of lactation for cows offered grass silage of low (L) or average (A) energy concentration alone or when maize silage contributed 25,50 or $75 \%$ of forage $D M$

\begin{tabular}{|c|c|c|c|c|c|c|c|c|c|}
\hline \multirow[b]{2}{*}{$\%$ Maize } & \multicolumn{4}{|c|}{ Grass silage $L$} & \multicolumn{4}{|c|}{ Grass silage $A$} & \multirow[b]{2}{*}{ R.S.D.* } \\
\hline & 0 & 25 & 50 & 75 & 0 & 25 & 50 & 75 & \\
\hline Number of cows & 12 & 12 & 11 & 11 & 10 & 12 & 11 & 12 & - \\
\hline $\begin{array}{l}\text { Silage DM intake } \\
\text { (kg/day) }\end{array}$ & 6.9 & $7 \cdot 5$ & $8 \cdot 1$ & 8.7 & $8 \cdot 0$ & $8 \cdot 1$ & $9 \cdot 4$ & $8 \cdot 1$ & 1.04 \\
\hline Milk yield (kg/day) & $23 \cdot 8$ & $24 \cdot 6$ & $24 \cdot 7$ & $26 \cdot 3$ & $24 \cdot 5$ & $25 \cdot 4$ & $26 \cdot 4$ & $25 \cdot 3$ & $2 \cdot 39$ \\
\hline \multicolumn{10}{|l|}{ Milk composition $(\mathrm{g} / \mathrm{kg}$ ) } \\
\hline Fat & 38.8 & $39 \cdot 8$ & $37 \cdot 8$ & $38 \cdot 4$ & $39 \cdot 4$ & $38 \cdot 1$ & $38 \cdot 4$ & $38 \cdot 4$ & $2 \cdot 83$ \\
\hline Protein & $30 \cdot 2$ & $31 \cdot 0$ & $30 \cdot 6$ & $30 \cdot 3$ & $30 \cdot 9$ & $31 \cdot 1$ & $30 \cdot 5$ & $30 \cdot 9$ & $1 \cdot 54$ \\
\hline Lactose & $46 \cdot 1$ & $46 \cdot 5$ & $46 \cdot 6$ & $46 \cdot 7$ & $46 \cdot 6$ & $46 \cdot 5$ & 46.8 & $46 \cdot 8$ & $1 \cdot 13$ \\
\hline \multicolumn{10}{|l|}{$\begin{array}{l}\text { Yield of milk constituents } \\
\text { (g/day) }\end{array}$} \\
\hline Fat & 923 & 979 & 934 & 1010 & 965 & 967 & 1014 & 971 & 113 \\
\hline Protein & 719 & 762 & 756 & 797 & 757 & 790 & 805 & 782 & 61 \\
\hline Lactose & 1097 & 1144 & 1151 & 1228 & 1142 & 1181 & 1236 & 1184 & 123 \\
\hline Liveweight (kg) & 539 & 538 & 548 & 562 & 553 & 565 & 568 & 552 & $26 \cdot 8$ \\
\hline Liveweight change (kg) & $-5 \cdot 2$ & -6.6 & $-1 \cdot 5$ & $4 \cdot 6$ & $14 \cdot 5$ & $27 \cdot 3$ & $11 \cdot 5$ & $-2 \cdot 4$ & $32 \cdot 48$ \\
\hline
\end{tabular}

* Residual standard deviation used owing to unequal replication. R.S.D. and number in treatment can be used to obtain appropriate standard error.

was a significant $(P<0.01)$ linear effect of maize proportion on adjusted protein yield with grass silage $L$, the regression coefficient being $0.8 \pm 0.03 \mathrm{~g} /$ day per percentage maize proportion. For grass silage $A$ there was a significant quadratic relationship between protein yicld and grass:maize ratio with the 1:1 mixture giving the highest yield.

Liveweight and liveweight change were not significantly affected by proportion of maize, although the individual treatment means tended to follow a similar pattern to that seen for silage intake. Both liveweight and liveweight change were significantly $(P<0.05)$ affected by grass silage quality, the adjusted means for liveweight being 547 and $559 \mathrm{~kg}$ and for liveweight change, $2.1 \mathrm{~kg}$ and $12.7 \mathrm{~kg}$ for silages $L$ and $A$, respectively.

\section{DISCUSSION AND CONCLUSIONS}

Increasing the in vitro digestible organic matter in dry matter (DOMD) value of grass silage from 620 (grass silage $L$ ) to 660 (grass silage $A$ ) $\mathrm{g} / \mathrm{kg}$ led to an increase in silage DM intake of $0.28 \mathrm{~kg} / 10 \mathrm{~g}$ per $\mathrm{kg}$ increase in digestibility value. This response is in line with earlier work reported by Thomas (1980) and Moisey \& Leaver (1984). A similar increase of $38 \mathrm{~g} / \mathrm{kg}$ in the in vitro DOMD value was produced by mixing $250 \mathrm{~g} / \mathrm{kg}$ DM of grass silage $L$ with $750 \mathrm{~g} / \mathrm{kg}$ DM of maize silage, which resulted in an in vitro DOMD value of the mixture of $670 \mathrm{~g} / \mathrm{kg}$ DM. In this case, silage DM intake was increased by $0.47 \mathrm{~kg} / 10 \mathrm{~g}$ rise in in vitro
DOMD value of the forage mixture. Even when the digestibility value of grass silage (silage $A$ ) was similar to that of maize silage, the inclusion of maize silage as part of the forage ration led to increased intake, indicating that the increase in intake was not due solely to increased digestibility. The present experiment showed that the incorporation of maize silage into dairy cow rations based on these grass silages had the potential to increase forage intake substantially.

These results confirm the earlier preliminary studies carried out in the UK (Weller \& Phipps 1985, 1986; Phipps et al. 1988) and studies from other countries that have recently been reviewed (Pflimlin 1990; Phipps 1990). It should be noted, however, that in the present experiment the response in intake may have been limited, as rations were not formulated to be isonitrogenous. The $\mathrm{CP}$ concentration of the rations containing $0,250,500$ and $750 \mathrm{~g}$ maize silage $\mathrm{DM} / \mathrm{kg}$ forage DM declined as the proportion of maize silage in the ration increased and were $c .170,160,150$ and $140 \mathrm{~g} / \mathrm{kg}$ DM, respectively. The two lower CP concentrations would, according to Kung \& Huber (1983), almost certainly have depressed intake. There is a clear need for further work to be carried out with isonitrogenous diets.

The present study confirms earlier work carried out in the UK which showed that the incorporation of maize silage into grass silage based diets can increase milk yield substantially. Where the current experiment differs from earlier work is that a significant overall linear effect of level of maize inclusion on milk yield 
has been established. This suggests that in order to derive maximum benefit in terms of milk yield, maize silage should form at least $50 \%$ of the forage DM. In many countries where maize silage is successfully grown and extensively used in dairy production systems, an inclusion rate of $75 \%$ of the forage DM is common.

Whereas milk protein concentration was unaffected by treatment in the present experiment, results reported from Japan (Izumi et al. 1982) have shown that the incorporation of maize silage into grass silage based rations increased milk protein concentration. These increases were attributed to an increased DM and hence energy intake. Although energy intake would have been increased in the present trial by the incorporation of maize silage in the rations, the lack of response in milk protein concentration may have been due to the fact that the CP content of the total diet fell as the proportion of maize increased, thus offsetting the positive effects of increased energy intake. Although milk fat concentration was unaffected in the present trial, it is possible to envisage a depression in milk fat synthesis if a large proportion of the forage ration is mature maize silage with a high grain content and hence high starch content, which is fed in conjunction with a moderate to high level of a starch based concentrate. Further work is needed to determine the optimum composition of supplements for rations in which mature maize silage forms a major part.

In conclusion, the present work suggests that farmers in climatically suitable areas in the UK should consider the integration of maize silage into dairy cow rations based on grass silage.

The authors would like to thank J. Siviter, A. Cooper and P. D. C. Ridpath for assistance in the conduct of the experiment.

\section{REFERENCES}

Izumi, Y., Kurosawa, H., Ohura, N., Ishida, S. \& Onoe, $S$. (1982). Effect of feeding various levels of grass silage and corn silage to lactating dairy cows. Japanese Journal of Zootechical Science 53, 686-691.

KunG, L. \& Huber, J. T. (1983). Performance of high producing cows in early lactation fed protein of varying amounts, sources and degradability. Journal of Dairy Science 66, 227-234.

MoISEY, F. R. \& Leaver, J. D. (1984). A study of two cutting strategies for the production of grass silage for dairy cows. Research and Development in Agriculture 1, 47-52.

Pain, B. F. \& Phipps, R. H. (1975). The energy to grow maize. New Scientist 66, 394-396.

Pflimlin, A. (1990). The place of maize in French livestock production. In Milk and Mean from Forage Crops (Ed. G. C. Pollott), pp. 127-136. Peebles, Scotland: Occasional Symposium No. 24, British Grassland Society.

Phipps, R. H. (1990). Maize: A review of research findings in relation to animal production: In Milk and Meal from Forage Crops (Ed. G. C. Pollott), pp. 107-119. Peebles, Scotland: Occasional Symposium No. 24, British Grassland Society.

Phipps, R. H., Weller, R. F., Elllott, R. J. \& Sutton, J. D. (1988). The effect of level and type of concentrate and type of conserved forage on dry matter intake and milk production of lactating dairy cows. Journal of Agricultural Science, Cambridge 111, 179-186.

Thomas, C. (1980). Conserved forages. In Feeding Strategies for Dairy Cow's (Eds W. H. Broster, C. L. Johnson \& J. C. Tayler), pp. 8.1-8.14. London: Agricultural Research Council.

Weller, R. F. \& PhipPS, R. H. (1985). Milk production from grass and maize silages. Animal Production 40, 560-561 (Abstract).

Weller, R. F. \& Phipps, R. H. (1986). The effect of silage preference on the performance of dairy cows. Animal Production 42, 435 (Abstract). 